\title{
THE »BOCKHOLM CONGLOMERATE» - AN INTRUSIVE BRECCIA IN ÅLAND, SW FINLAND
}

\author{
CARL EHLERS
}

\begin{abstract}
EHLERS, CARL 1979: The "Bockholm conglomerate» - an intrusive breccia in Aland, SW Finland. Bull. Geol. Soc. Finland 51, 17-25.

Three breccias composed of a heterogeneous mixture of rock fragments in a clastic matrix have been studied in the Enklinge area, southwestern Finland. One of them is the "Bockholm conglomerate», by Sederholm considered as a basal conglomerate for the Bothnian formation. The breccias intrude into the surrounding Svecofennian volcanics and tonalites. Minor intrusions of quartz porphyry and plagioclase porphyry accompany the breccias. On Bockholm the breccia and the porphyry are weakly mineralized by chalcopyrite and arsenopyrite. It is proposed that the breccias form small intrusive pipes connected to, but younger than, the intrusion of the tonalites.
\end{abstract}

Carl Ehlers, Geologisk-mineralogiska Institutionen, Åbo Akademi, SF-20500 Abo 50, Finland.

\section{Introduction}

In his stratigraphic scheme for the Svecofennian rocks of south-western Finland, J. J. Sederholm (1932) recognized two different formations of supracrustal rocks. The classification was based upon the age relationships between the schists and volcanics on the one hand and the granitoid rocks of different ages on the other. The Bothnian formation, characterized by basic and intermediary volcanics was, according to Sederholm (1932), younger than the trondhjemitic - granodioritic gneissose granites (granites of the first group), while the Svionian schists, including the leptite formation in southern Finland, were older than the genissose granites. The Bothnian formation represented a second cycle of supracrustal rocks deposited on top of a deeply denuded basement consisting of metamorphosed Svionian supracrustals and gneissose granites. For a historical outline of the stratigraphic classification of the rocks in south-western Finland, see Simonen (1953).

Among the areas in south-western Finland, considered by Sederholm to consist of Bothnian volcanics, is the Enklinge area in the eastern archipelago of the Alland Islands (Fig. 1). The map of the $»$ Bockholm conglomerate» was published by Sederholm 1930 and the description four years later (Sederholm 1934). In his paper (1934) Sederholm describes a small outcrop of "conglomerate» on the island of Bockholm southeast of Enklinge (Fig. 1). The »conglomerate» is at the contact between the volcanics of Enklinge (Bothnian) and the surrounding gneissose granite. Nu- 


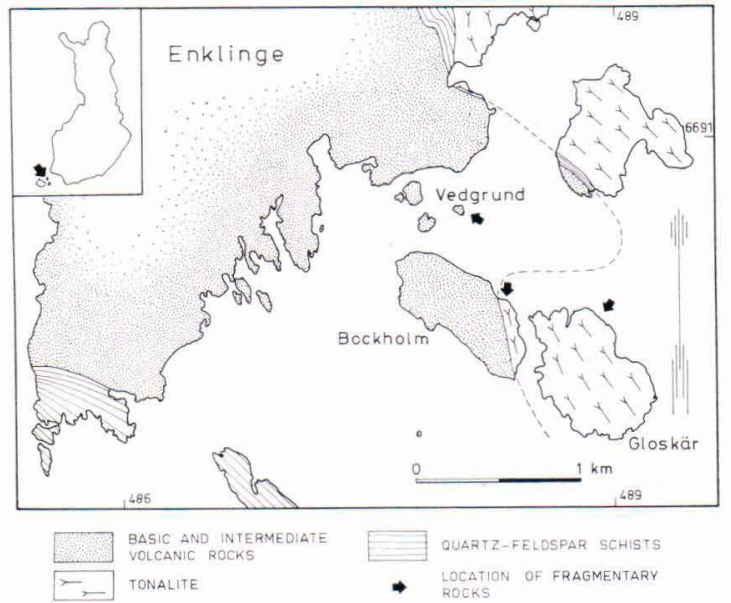

Fig. 1. The locations of fragmentary rocks in the Enklinge area.

merous rounded fragments of the same granite gave the "conglomerate» an additional stratigraphic significance. It is not surprising that Sederholm immediately accepted the rock as a basal conglomerate proving that the volcanics are deposited on top of a basement of gneissose granite.

However, after having visited Bockholm, Magnusson (1936) called the rock a pseudoconglomerate, caused by tectonical forces breaking up intersecting dikes of gneissose granite. As the supracrustal rocks of Kumlinge and Enklinge all belong to the same stratigraphical succession (Rancken 1953, Ehlers 1976) and as the proofs of the existence of a Bothnian formation generally are unsatisfactory, the »conglomerate» of Bockholm has been re-examined.

The rock that Sederholm (1934) called gneissose granite comprises several granitoids of slightly different compositions. According to Ehlers (1978) the rock on Enklinge and Bockholm is a tonalite and this name is used in the following sections. Fragmentary rock is used as a descriptive non-genetic term for the different types of breccias and conglomerate-like rocks.

\section{The distribution of fragmentary rocks}

The basic and intermediary rocks in the Enklinge area lie in a syncline and they constitute a fairly well preserved local volcanic centre. The rock sequence within the syncline starts at the bottom with quartz-feldspar schists and intercalated layers of crystalline limestone, followed by pillow lavas, pillow breccias and polygonally jointed amphibolitic lavas (Ehlers 1976). The Enklinge syncline is surrounded by an intrusive tonalite (Ehlers 1978, Fig. 6).

Fig. 1 shows that the outcrop of fragmentary rock on Bockholm, originally described by Sederholm as a conglomerate, is situated at the contact between the volcanics and the tonalite.

In 1976 two more outcrops of fragmentary rocks, resembling the original "conglomerate» of Bockholm were found in the surroundings. On the little islet of Vedgrund (Fig. 1) between Bockholm and Enklinge there is a set of narrow pebble dikes. The dikes cut the amphibolitic pillow breccias and they contain sparse pebbles of a rock resembling the surrounding tonalite.

Another outcrop of fragmentary rock is on the island of Gloskär within the tonalite massif (Fig. 1). The fragmentary rock on Gloskär is associated with a light mediumgrained plagioclase porphyry that cuts through the tonalite.

\section{The fragmentary rock and associated porphyry on Bockholm}

The outcrop, which is completely exposed was mapped by Sederholm 1930 and described 1934. It is situated on the northeastern shore of Bockholm and it measures some $30 \times 10$ metres (Fig. 2). The rock consists of a well mixed mass of fragments that vary greatly in size, rounding and rock type 


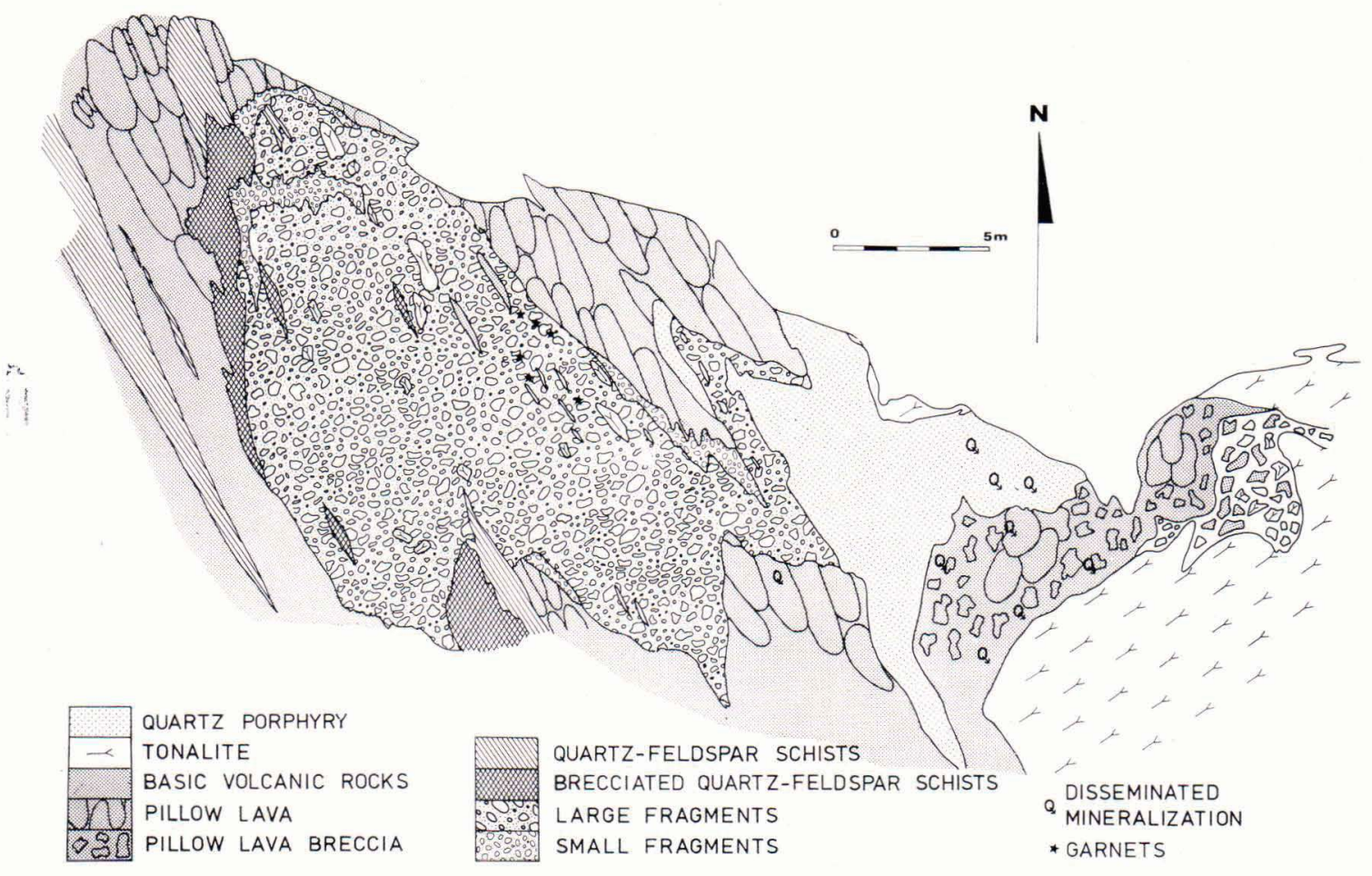

Fig. 2. The fragmentary rock on Bockholm.

(Figs. 3, 4). The fragments represent local rock types and rounded pebbles of tonalite are conspicuous (Fig. 3). The matrix is a medium-grained clastic rock paste composed of the same material as the fragments, filling the insterstice between them.

Along the margins of the outcrop of fragmentary rock there is a zone, up to a metre wide, comprising smaller fragments, some of which have a dark amphibole-rich crust (Fig. 2). A layer of quartz-feldspar schist can be followed through the marginal zone as a train of angular fragments which seem to lie almost in their original positions (Fig. 5). In Fig. 2 the rock is plotted as brecciated quartzfeldspar schist.

The fragmentary rock shows the same type and amount of deformation as the surrounding rocks, the main structural feature being a strong mineral lineation coupled with a weak schistosity. The fragments are elongated parallel with the mineral lineation and flattened parallel with the schistosity. Large garnets have grown in some parts of the matrix.

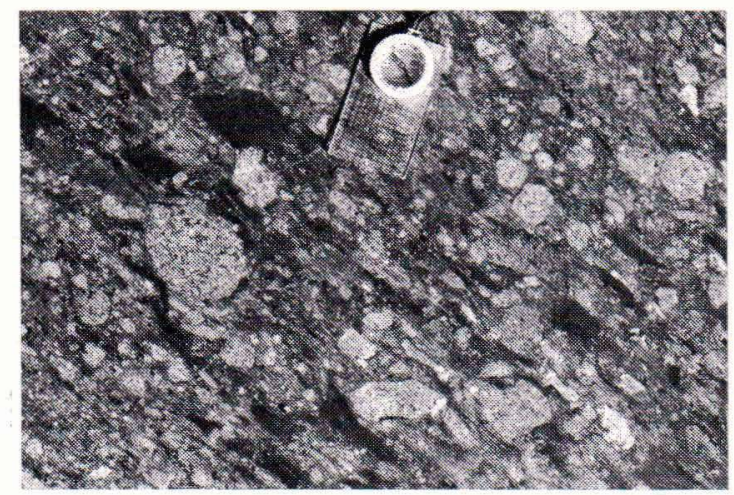

Fog. 3. Fragments of varying size, roundness and rock type from the central parts of the fragmentary rock on Bockholm. 


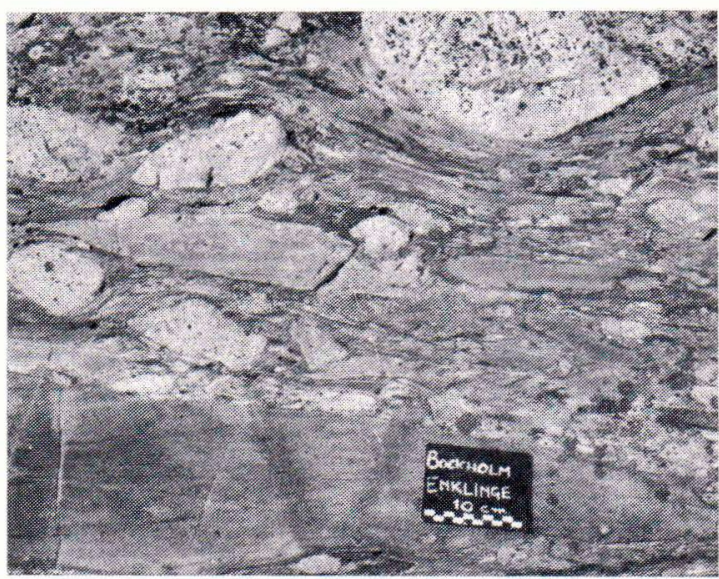

Fig. 4. Large slab of amphibolite and rounded pebbles of tonalite embedded in a matrix consisting of a medium-grained rock flour. Bockholm.

The fragmentary rock is surrounded by amphibolitic pillow lavas and pillow lava breccias (Fig. 2). The contact against the lavas is sharp, showing that the fragmentary rock cuts them discordantly (Fig. 6). There-

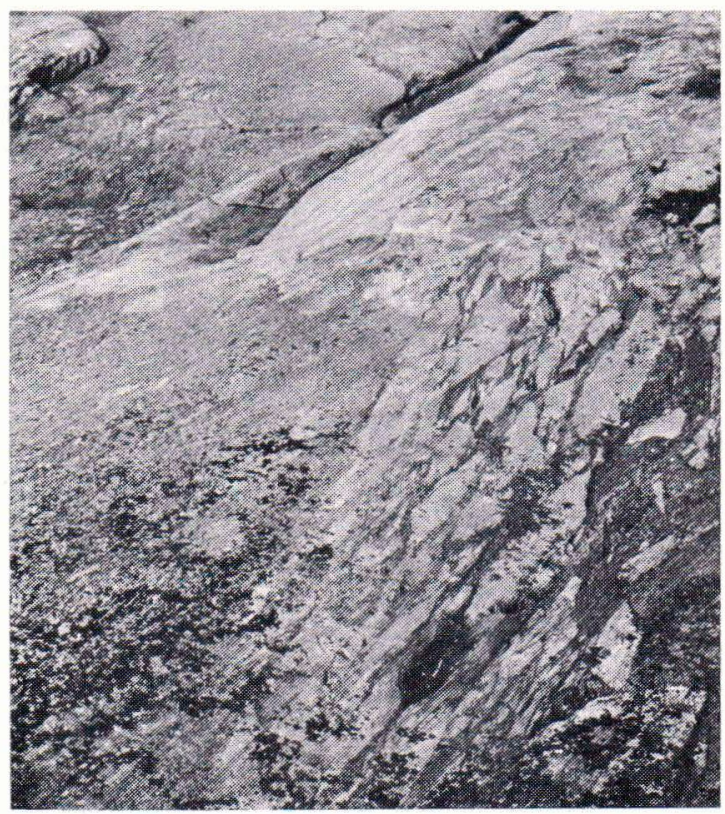

Fig. 5. Angular fragments of quartz-feldspar schist forming a zone of brecciated rock along the western contact of the fragmentary rock. Bockholm. fore, the fragmentary rock on Bockholm must be younger than the volcanic rocks of the Enklinge syncline.

Associated with the fragmentary rock there is a light medium-grained quartz-feldspar rock that differs from the earlier mentioned quartz-feldspar schists. On Sederholm's map this rock is called »schistose arcose» (Sederholm 1934) and he considered it a part of the »conglomerate». A closer examination reveals that the quartz-feldspar rock is intrusive into the tonalite (and possibly also into the fragmentary rock) and that it contains small rounded fragments of tonalite. The intrusive quartz-feldspar rock carries small rounded quartz "eyes» in a grey matrix and here it is called a quartz porphyry.

Under the microscope the quartz »eyes» can be seen to be rounded, sometimes with idiomorphic outlines. Bipyramidal quartz megacrysts are common. They are $3-4$ millimetres in diameter and usually have embayed margins and inclusions of groundmass. Many quartz megacrysts are unstrained, but some grains show signs of strain, and growth of subgrains. This implies a fairly complicated history with possible growth of porphyroblastic quartz grains (Hopwood 1976).

The groundmass is mostly fine-grained, consisting of plagioclase and quartz in a heterogeneous granoblastic polygonal texture. The plagioclase has the composition of oligoclase-andesine. Biotite and cummingtonite occur in differing amounts, in part as megacrysts and aggregates. The biotite is partly transformed to chlorite. Strongly granulated and sericitized megacrysts of plagioclase are common and they can sometimes be seen only as aggregates of sericite and epidote. Epidote and calcite are present in all studied thin sections. The calcite is normally intermingled with sericite and epidote. Titanite is abundant in all thin sections.

Small stringers of strain-free quartz and opaques (chalcopyrite), coarser than the 


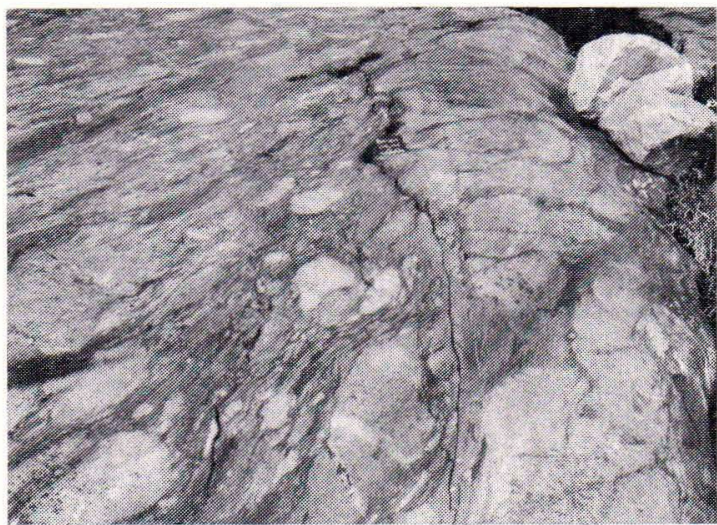

Fig. 6. The contact between the fragmentary rock and the surrounding pillow lavas. The lava structures are cut by the fragmentary rock. Bockholm.

groundmass, indicate a partial recrystallization. Table I shows examples of modal compositions and table II gives the chemical composition of one analysed sample of the quartz porphyry.

The quartz porphyry and the pillow lava breccia at the eastern contact of the fragmentary rock (the contact against the tonalite, Fig. 2) are weakly mineralized by arsenopyrite and chalcopyrite. Along the contact, patches and veins of arsenopyrite and chalcopyrite occur in both rock types. In the quartz porphyry chalcopyrite is irregularly distributed as tiny disseminated grains of less than a millimetre in diameter up to large aggregates a few centimetres in diameter. The porphyry shows no visible signs of mineralization on the outcrop.

\section{Fragmentary rock and associated porphyry on Gloskär}

On the northern shore of the island of Gloskär a fragmentary rock cuts through the surrounding tonalite. The outcrop on Gloskär is much larger than that on Bockholm and its area is difficult to estimate because it is largely covered by water and vegetation. Fig. 7 shows only a small part of the outcrop.

The fragmentary rock on Gloskär contains few rounded fragments and its appearance is not that of a conglomerate (Fig. 8). Angular or sub-rounded fragments of diorite and gabbro are abundant while fragments of tonalite are less frequent. Gabbros and diorites are not found in the immediate vicinity of this area. The fragments on Gloskär are more compacted and the rock as a whole is more "fused" compared with the conglomerate-like rock on Bockholm. The matrix consists of ground fragments, a rock flour similar to the matrix of the fragmentary rock on Bockholm.

The fragmentary rock is partially surrounded by a medium-grained, light quartz-
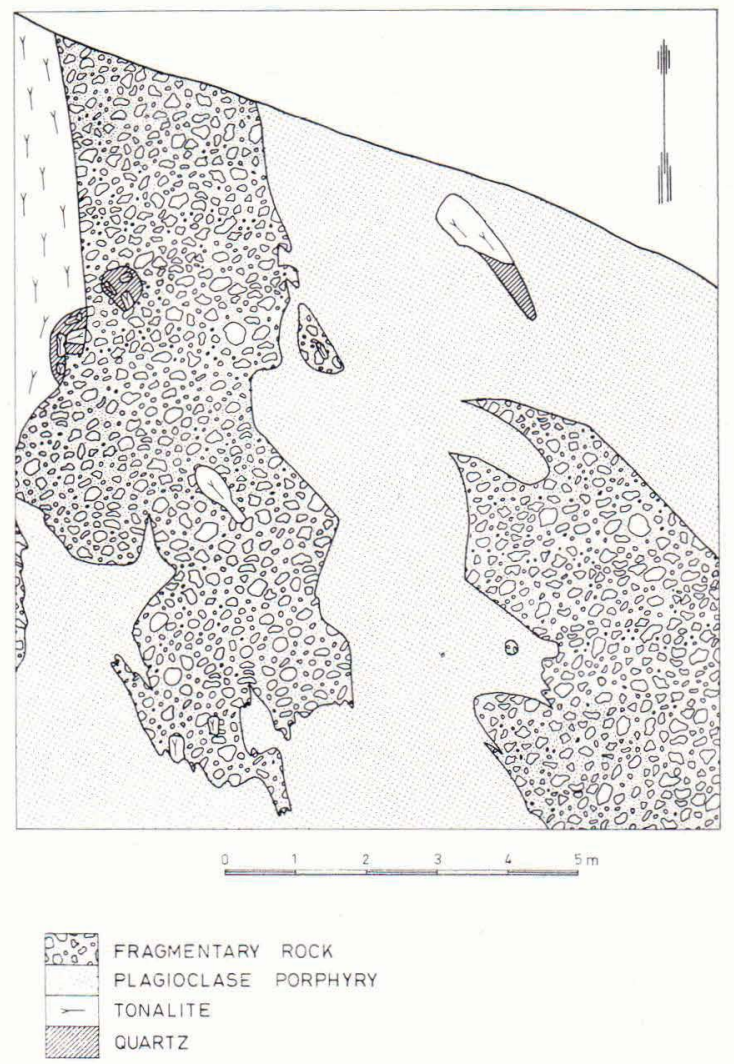

Fig. 7. Map of a small area within the fragmentary rock on Gloskär. 
Table 1. Point-counted modal analyses of the porphyries on Gloskär (Nos. 1, 2, 3), and Bockholm (Nos. 4, 5).

\begin{tabular}{lrrrrr}
\hline & 1 & 2 & 3 & 4 & 5 \\
\hline & & & & & \\
Quartz & 31.6 & 35.3 & 24.7 & 44.5 & 43.0 \\
Plagioclase & 59.4 & 54.6 & 59.6 & 31.8 & 37.1 \\
Biotite & 2.8 & 0.9 & 0.3 & 16.8 & 0.4 \\
Amphibole & 2.8 & 4.5 & 11.2 & & 10.9 \\
Chlorite & 1.6 & 2.2 & 0.3 & 3.2 & 0.1 \\
Epidote & 1.1 & 1.5 & 1.2 & 2.4 & 5.0 \\
Calcite & & 0.4 & 1.2 & 0.3 & 1.7 \\
Titanite & & & 1.2 & 0.1 & 1.4 \\
Opaque & 0.4 & 0.3 & & 0.1 & \\
\cline { 2 - 6 } & 99.7 & 99.7 & 99.7 & 99.2 & 99.6 \\
\hline
\end{tabular}

and feldspar-rich rock that is crushed, forming a shatter breccia of compacted randomly oriented angular fragments (this rock is not visible in Fig. 7). The spaces between the fragments are filled with aggregates of amphibole, chlorite, epidote, and calcite, forming a pattern of roughly triangular dark areas delimiting the fragments (Fig. 9). The shatter breccia merges gradually into the surrounding tonalite.

Intrusive into both the tonalite and the fragmentary rock is a light medium-grained rock spotted by abundant plagioclase megacrysts of some millimetres in diameter. It

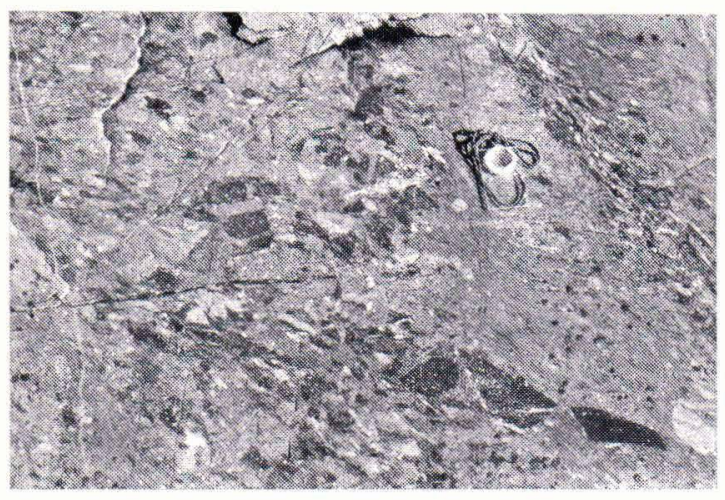

Fig. 8. Mixed fragments on Gloskär. The rock is more breccialike compared with that on Bockholm (Fig. 3, 4).
Table 2. Chemical analysis of the quartz porphyry on Bockholm.

\begin{tabular}{lr}
\hline & \\
$\mathrm{SiO}_{2}$ & 63.70 \\
$\mathrm{Al}_{2} \mathrm{O}_{3}$ & 15.10 \\
$\mathrm{Fe}_{2} \mathrm{O}_{3}$ & 6.89 \\
$\mathrm{FeO}$ & \\
$\mathrm{MgO}$ & 3.85 \\
$\mathrm{CaO}$ & 3.89 \\
$\mathrm{Na} 2 \mathrm{O}$ & 2.40 \\
$\mathrm{~K}_{2} \mathrm{O}$ & 2.00 \\
$\mathrm{CO}_{2}$ & 0.10 \\
$\mathrm{TiO}_{2}$ & 0.44 \\
$\mathrm{P}_{2} \mathrm{O}_{5}$ & 0.046 \\
$\mathrm{H}_{2} \mathrm{O}+$ & 1.61 \\
$\mathrm{Cu}^{\mathrm{Mo}}$ & 0.44 \\
& 0.05 \\
\hline
\end{tabular}

forms a dyke, several metres wide, that cuts the tonalite and occurs as irregular masses and dykes within the fragmentary rock, cutting it and enclosing pieces of it (Fig. 10). There is a superficial similarity between the porphyries on Gloskär and Bockholm both in their intrusive behaviour and in hand specimens. The porphyries are intrusive into the tonalite and they contain small inclusions of tonalite and other rocks which make their composition and texture variable. Both rocks have a pronounced mineral lineation and seem to have taken part in the same deformation as the surrounding rocks.

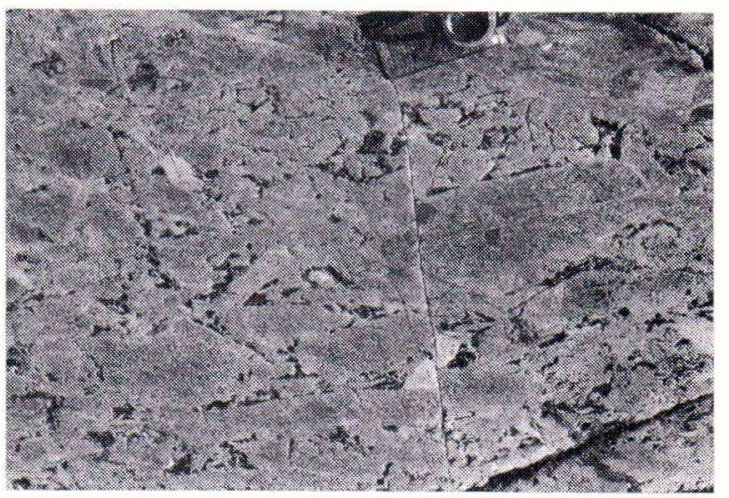

Fig. 9. Shatter breccia comparising densely packed angular rock fragments. This rock forms a zone around the mixed fragmentary rock. Gloskär. 


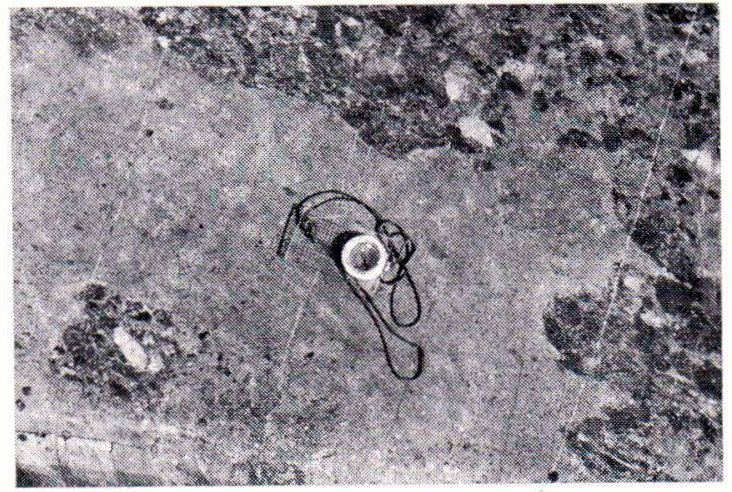

Fi.g 10. The plagioclase porphyry that cuts through the tonalite and the fragmentary rock on Gloskär.

The plagioclase porphyry on Gloskär lacks visible quartz »eyes». The rock is spotted with pale yellow plagioclase megacrysts a few millimetres in diameter. The microscopic investigation reveals that the rock is a placioclase porphyry with abundant idiomorphic and zoned megacrysts of oligoclase-albite. Sparse strongly sericitized and epidotized megacrysts of older plagioclase are common. A few rounded aggregates of quartz with recrystallized subgrains form »eyes» reminiscent of those on Bockholm.

The matrix of the plagioclase porphyry is more coarse-grained than that of the quartz porphyry on Bockholm, and the quartz is, with few exceptions, strain-free. Large aggregates of cummingtonite are found together with chlorite, epidote, calcite, and titanite. With the exceptions of sparse small grains of chalcopyrite the plagioclase porphyry is barren. Table I shows examples of the modal composition.

\section{Pebble dykes on Vedgrund}

On the little islet of Vedgrund, north of Bockholm, there is a swarm of narrow (5-10 $\mathrm{cm}$ wide) dykes consisting entirely of rock fragments of different sizes and types. The locality is situated about half a kilometre inside the area of volcanics (Fig. 1). The rock fragments represent local volcanic rock types, but single larger fragments of a tonalite-like rock can be found. The fragments vary in size and roundness and they are well mixed (Fig. 11). Rounded and subrounded fragments are abundant, and thus the dykes can be classed as pebble dykes (Bryner 1961) rather than breccia dykes. The pebble dykes on Vedgrund cut through the volcanics. They are deformed together with the country rock showing the same strong elongation of the fragments and the same mineral lineation. The pebble dykes have probably intruded at approximately the same time as the fragment rocks on Bockholm and Gloskär. With the

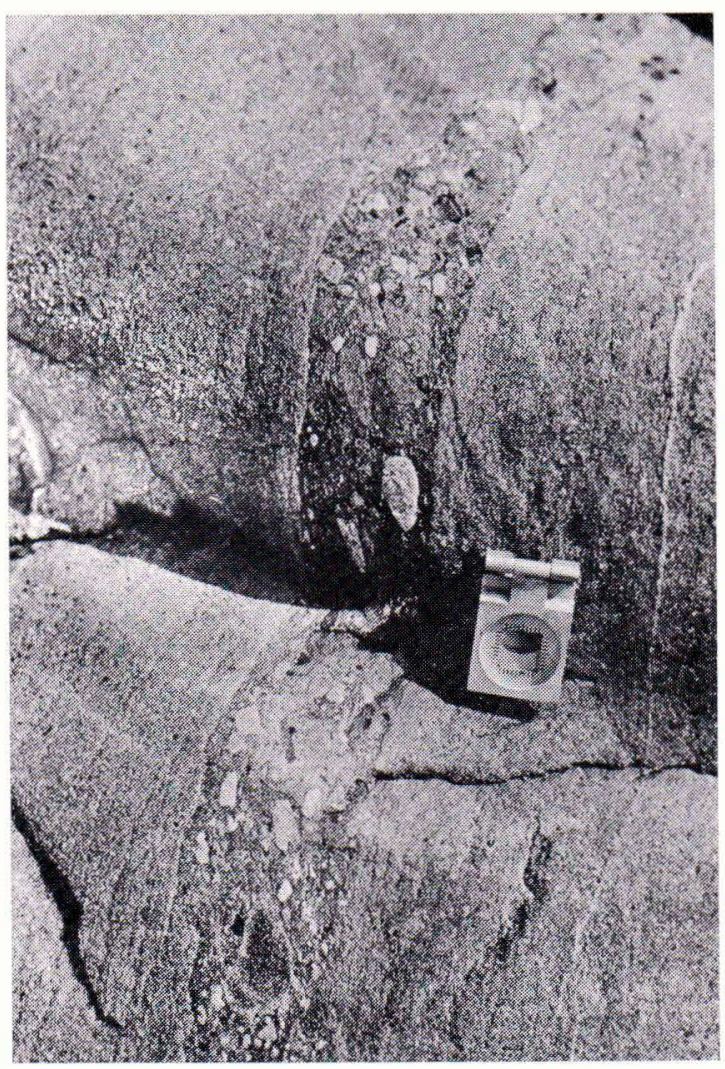

Fig. 11. A thin pebble dike cutting through amphibolite volcanics on Vedgrund. Many pebbles are well rounded. 
exception of minute amounts of sulphides the dykes are barren.

\section{Discussion}

The mixed fragments of different size, roundness, and rock type as well as the abundance of tonalite fragments are features that the fragmentary rocks on Bockholm and Gloskär have in common. The shatter breccia on Gloskär and the marginal zone of the Bockholm breccia are corresponding parts of an internal zonal structure within the fragmentary rocks. The matrix in both localities is composed of a clastic rock paste of the same material as the fragments. Many of these features can also be found in the pebble dykes on Vedgrund.

The characteristics listed above agree well with those listed by Bryner (1961) as characteristic of breccia columns or pebble columns. Bryant (1968) proposed the term intrusive breccia for the same type of rocks, which he defined as "a heterogeneous mixture of angular to rounded fragments in a matrix of clastic material that has been mobilized and intruded into its present position along preexisting structures» (Bryant 1968). Thus the most logical explanation for the origin of the fragmentary rocks in this area is that of intrusive breccias.

On Bockholm and Gloskär the intrusive breccias are associated with subsequent minor intrusions of porphyries which, in accordance with Sillitoe and Sawkins (1971) can be derived from the roof zones of an underlying late stage tonalite-dacite magma.

The mixed and rounded fragments indicate a process of fluid intrusion or fluidization as originally described by Reynolds (1954) and later by many authors, for example, Bryant (1968). The concept involves transportation and suspension of solid particles in an upward flowing medium of lower density than that of the fragments (Reynolds 1954).
The medium, which can be a liquid or a gas or both, is conceivably derived from a magmatic source. The fluid-gas moves upward along suitable zones of weakness carrying pieces of fractured rocks. More and more material is suspended and the fragments and matrix are mixed, rotated, and sometimes attrited and rounded. A weak hydrothermal mineralization followed on Bockholm, possibly in connection with the intrusion of the quartz porphyry.

The tectonic deformation of the intrusive breccias and pebble dikes indicate that the intrusion is related to, and closely follows, the syn-tectonic intrusion of tonalite. It is obvious that the tonalite has been solid and competent at the time of the breccia emplacement. The intrusive breccias could be caused by hydrothermal gases and fluids that together with the porphyries constitute the latest stage of the intrusion of the tonalite. According to Whitney (1977) a magma of tonalitic composition could have substantial vapour generation close to the surface.

Many authors have called attention to the significance of mineralizations in breccia pipes (Bryner 1961, Perry 1961, Bryant 1968, Gilmour 1977) and most of them agree that they might offer a clue to the existence of buried copper mineralizations. Hopwood (1976) concludes generally that $\gg$ the combined association of a) pyrite-rich units and b) a characteristic quartz-eye bearing porphyroidal acid rock type appears closely related to the occurrence of volcanogenic massive pyrite $\mathrm{Cu}-\mathrm{Zn}$ sulfide deposits».

It is conceivable that intrusive breccias of this type are more widespread than recognized earlier and that they are a feature connected with the late stages of intrusions of tonalites and granodiorites. Such a breccia is, for example, the Paronen copper mineralization in Ylöjärvi, which according to Himmi (1954) is »a result of an explosion-like gas outburst». Perry (1961) pointed out the 
similarities between the Chilean tourmaline breccia pipes and the breccias in Ylöjärvi.

The Ylöjärvi and Chilean breccias differ, however, from the Bockholm occurrence in their tourmaline-rich matrix and more extensive sulphide mineralization.

\section{References}

Bryant, Donald G. (1968) Intrusive breccias associated with ore, Warren (Bisbee) Mining District, Arizona. Economic Geology 63, 1-12.

Bryner, L. (1961) Breccia and pebble columns associated with epigenetic ore deposits. Economic Geology 56, 488-508.

Ehlers, Carl (1976) Homogenous deformation in Precambrian supracrustal rocks of Kumlinge area, southwest Finland. Precambrian Research $3,481-504$.

- (1978) Gravity tectonics and folding around a basic volcanic centre in the Kumlinge area, SW Finland. Geol.Survey of Finland Bull. 295. 43 p.

Gilmour, Paul (1977) Mineralized intrusive breccias as guides to concealed porphyry copper systems. Economic Geology 72, 290-303.

Himmi, R. (1954) The copper ore deposit of Paronen. in The mines and quarries of Finland, ed. by E. Aurola, Geological Survey of Finland, Geoteknillisiä julkaisuja 55. Pp. 15-16.

Hopwood, T. P. (1976) „Quartz-eye» bearing porphyroidal rocks and volcanogenic massive sulfide deposits. Economic Geology 71, 589612.

Magnusson, N. H. (1936) A short comparison between the evolution of the svecofennides in Finland and central Sweden. Bull. Comm. géol. Finlande 115, 179-183.

Perry, Vincent D. (1961) The significance of mineralized breccia pipes. Mining Engineering 13, $367-376$.
Acknowledgements - The author is grateful to professor Nils Edelman for critically reading the manuscript, and to Mary Ehlers, fil.mag. for assisting in the field work.

Christopher Grapes, BA, kindly checked the language.

Rancken, Ragnar (1953) Über eine archäische superkrustale Formation im Schärenhof von Kumlinge, Ålandsgebiet, SW-Finnland. Medd. fr. Åbo Akademi Geol.-Min. Inst. 35. 38 p.

Reynolds, Doris (1954) Fluidization as a geological process and its bearing on the problem of intrusive granites. Am.J.Sc. 252, 577-614.

Sederholm, J. J. (1930) Pre-Quaternary rocks of Finland. Bull. Comm.géol. Finlande 91.

- (1932) On the geology of Fennoscandia. Bull. Comm.géol. Finlande 98.

- , (Mikkola, E.) (1934) On migmatites and associated pre-Cambrian rocks of southwestern Finland, Part III. The Åland Islands. Bull. Comm.géol. Finlande 107. 68 p.

Sillitoe, R. H. and Sawkins, F. J. (1971) Geologic, mineralogic and fluid inclusion studies relating to the origin of copper-bearing tourmaline breccia pipes, Chile. Economic Geology 66, 1028-1041.

Simonen, Ahti (1953) Stratigraphy and sedimentation of the Svecofennic, early Archean supracrustal rocks in southwestern Finland. Bull.Comm.géol. Finlande 160. 64 p.

Whitney, James A. (1977) A synthetic model for vapor generation in tonalite magmas and its economic sanifications. Economic Geology 72, $686-690$.

Manuscript received, October 26, 1978 